Article

\title{
Remaking Slums: International Examples of Upgrading Neighbourhoods
}

\author{
Josep Maria Montaner \\ Escuela Técnica Superior de Arquitectura de Barcelona, Universitat Politècnica de Catalunya, \\ 08028 Barcelona, Spain; jose.m.montaner@upc.edu
}

Received: 19 October 2020; Accepted: 20 November 2020; Published: 26 November 2020

check for updates

\begin{abstract}
The slum, self-constructed houses and neighbourhoods, signifies the dwelling and home for a very representative part of humanity. This text analyses the different typologies and the different possible and ethical strategies for foreseeing, for remaking and for the resettlement of these self-produced neighbourhoods. Some study cases and examples as references are presented, such as Solanda neighbourhood in Quito, Ecuador, and the Favela-Bairro programme in Rio de Janeiro, Brazil. This article is situated in the field of housing studies and focused specially on architectural issues.
\end{abstract}

Keywords: self-produced neighbourhoods; self-construction policies; remaking slums; foreseeing affordable housing; Solanda neighbourhood model; Favela-Bairro Programme

\section{Introduction: A Necessary Research and Policy}

Beyond formal, conventional and academic urbanism, a lot of cities in many developing countries have a high percentage of informal and self-produced neighbourhoods, without basic public facilities and infrastructures, and without a minimum quality of life. In these cases, the urban fabric is formed by a collage of self-constructed houses, still in transformation, generally made with recycled materials. In the near future, slums will continue growing in big cities. According to the United Nations, the number of inhabitants living in slums increased from 777 million in 2000 to 828 million in 2010. By 2015, Sub-Saharan Africa had 332 million slum-shelters; in Latin America, 110 million people are living in precarious settlements, and 34 million of them in Mexico.

For this reason, it is vital and a priority to have tools to support and contribute to their success and liberation from systems of oppression. While formal urbanism has its very long written history, one difficulty for understanding and improving slums is that there is a very diverse kind of marginal and hybrid urbanism, and authentic world, which does not have its own written history. Having historicity is the first step towards tools for improvement. However, the cultural context is changing: since the 1990s, some books about slums and cooperation have been published [1-4].

The aim of this text is to make visible some of the experiences and studies in informal neighbourhoods, as a crucial objective in urban planning and housing architecture for social policy actions. As it is very difficult to be exhaustive in an article about a phenomenon like slums, when the social and health situation, political context and measures to improve them are very broad in all our planet and cities, this text analyses cases in Latin America, especially Mexico, Peru, Equator, Brazil and Argentina. The study cases are the result of visiting informal settlements (favelas, villas miseria, etc.) with different politicians, experts and professionals involved in the experiences of improvement.

\section{The Concept of Slum and the Diversity of Processes and Typologies}

The concept of slum was first used in England in the beginning of the 19th century to characterise little cottages where poor people lived, surrounded by degradation and criminality. In the middle of the 19th century, the term was extended to France, North America and India [5]. 
It is a very broad term, that adopts different names-"shanty towns" in Asia, "favelas" in Brazil, "villas miseria" in Argentina, "pueblos jóvenes" in Peru, "bidonvilles" in francophone North Africa, etc., which we can use to characterise informal and self-produced neighbourhoods, with a horizontal and overcrowded morphology, living in very small and precarious houses and working, generally, in an informal economy, in a kind of rural and urban hybridisation. Slums grow as a informal-urbanism, where poor and marginalised people live with uncertainly and insecurity of tenure. They lack adequate access to services, drinkable water, appropriate health conditions and public transportation networks. In sum, they lack public goods and services.

If we take as a reference the case of Lima, in Peru, the self-construction process of the slums has different phases. The first one is the occupation of the plot of land. Especially in the 1960s and 1970s, people were self-organised, but in recent decades, the occupation has been related to pirate urbanisation, made by private and illegal entrepreneurs. People self-built precarious constructions that are improved over time and depend on their possibilities. Neighbours try not to be evicted and to be accepted and legalised through urban plans. In the next phase, inhabitants would fight to have rights to drinkable water, light, sewers and drains, public facilities and public transportation-all in all, to be legalised and included in the urban structure.

Under very different conditions (countries, sites, topographies, materials and social networks), there are very different typologies of slums: from the very provisional barracks to self-constructed neighbourhoods with some structure; from small sites to big territories with millions of inhabitants, as in Ciudad de Mexico (6.6 million people) or in Kibera, Nairobi, Kenya (1 million); from neighbourhoods in the dry mountains in Lima to "palaphita" structures in Manila, in floodable sites. Visiting big cities in India, especially Delhi, Calcutta or Mumbai, you can clearly see the very different kinds of slums, from the poorest, contaminated and fragile, near to roads and railway systems, to the most consolidated, that have an urban morphology similar to mediaeval, traditional and artisanal Indian old structures of "cottages", which Mahatma Gandhi preferred for people in India [6].

Faced with the question of people living in slums, it can be considered that there are three main positive alternatives: foreseeing the problem of the lack of housing by projecting and building popular and affordable basic houses before people have to build their own houses; remaking and remodelling the slums by improving the living conditions; or resettling and relocating people from sites with different kinds of problems, such as contamination in soil and waters and landslide hazards, or work for infrastructures for the common good, to nearby plots with better urban conditions [7].

However, these resettlements and other types of interventions, such as the removal of slums and moving people to other areas, are not acceptable if they are evictions against the will of inhabitants and do not uphold human rights, the basic principles and guidelines on evictions and displacement. This is especially delicate in the case with families with children and pregnant women, and during inclement weather, at night and in conditions of contagious and infectious diseases [8].

\section{Self-Construction Policies}

One of the ways of foreseeing the construction of popular houses on the periphery of cities has been through so-called "self-construction policies". From the 1960s and 1970s onwards, the "self-construction policies" meant that societies, politicians and professionals began to accept the informal city as a fact. This led to a partial acceptance and the legalisation of self-production in some countries and cities in Latin America. Different states, regions and cities promoted "self-produced neighbourhoods", providing the structure of the streets, pavements and squares, the plots of land, the urbanisation, minimum services and some material, technical and financial support.

This new mentality has different roots especially in Patrick Geddes's theories and projects, from the beginning of the 20th Century [9] and in the self-construction proposal of John Turner's "Housing by people: Towards Autonomy in Building Environments (1976), which was a result of the English tradition of Anarchist urbanism and defending poor neighbourhoods, introduced by Colin Ward [10] 
and Charles Adams. One of Turner's famous sentences in Brazil during the 1960s was that "favelas are less the problem than the solution" [11].

The biologist, activist and planner Patrick Geddes (1854-1932), especially during his stay in India from 1915 to 1919, proposed the "Conservative surgery" solution, which implied rejecting formal and imposed urban design. Geddes proposed to begin with observation, a "civic survey", and a patient study in every part of the city where the renewal was necessary, so as to have information for a "diagnostic survey". The goal was to plan according to the latent characteristics of a particular site and situation (structure of the plots, the quality of old housing, heritage, vegetation, popular public spaces, social networks), not by the imposition of geometrical axes. Geddes projected a minimum number of roads and a maximum number of open spaces, which should be planted with trees. He saw the processes of repair, renewal and rebirth as a natural phenomenon of development [12].

Among the very different contemporary examples of "self-construction politics", there is the case of Colonia La Fama, by the Cooperativa La Unión, in Santa Catarina, during the 1970s, in Monterrey, Mexico. Providing the land and the basic urban design and infrastructures by administration, neighbours self-produced their houses and now this neighbourhood has a high quality of urban life, with urban diversity created by self-constructed and coloured houses, small shops and a lot of trees planted by people.

One of the most interesting ones-and successful until now-is the case of Solanda, a very popular and large area in the south of Quito, Ecuador, planned as a "model neighbourhood". This part of the city has 155 hectares, with wide streets and a complex system of neighbourhood units and a different scale of squares. Solanda was constructed on a very big urban plot, assigned by a philanthropist, Maria Augusta Urrutia, in 1974, through the Mariana de Jesús Foundation, and giving each family one small lot. The urban plan was projected by the architects Ernesto Guevara, Juan Fernando Pérez, Adolfo Olmedo, Roberto Miño García, Fernando Bajana, Ramiro Villalba, Homero Sandoval, Walter Moreno y Ernesto Dighero. With funds from the Banco Ecuatoriano de Vivienda and technical help by Junta Nacional de la Vivienda, each lot began with four pillars, one floor, one sanitary unit (bath and kitchen), and a "canalit" corrugated roof. All these elements allowed families to build and add on to their houses over time and according to their financial means. The self-construction began in 1984 and the final result was a neighbourhood with urban order; an adequate standard of services and shops; a high quality of facilities for education, sport and leisure; and an authentic formal variety with different façades, materials, colours, exterior stairs and heights, as a result of the self-construction process, based on suitable and planned urban structure. The majority of the neighbours, some of whom worked in the construction sector, participated in the building and improvement of Solanda. Today, Solanda is a very popular and desired area in Quito. It is true that there are the ordinary maintenance problems and needs, but Solanda is a benchmark of urban quality obtained as a result of the fights and strategies of neighbourhood associations and collective action by the community during decades.

Other examples of self-construction as a concept of expandable housing are the well-known PREVI contests (Proyecto Experimental de Vivienda), in Lima (1966-1975), a new neighbourhood with growing housing, projected by international and equatorial teams of architects who were experts in housing (Atelier 5, James Stirling, Christopher Alexander, Aldo van Eyck, etc.) [13], and the Elemental in Chile (from 2003), also based on an international contest for incremental housing models, that achieved qualified results in some of the cases [14]. This was not the case of Tondo, in Manila; one international contest, organised by the Architectural Record and L'Architecture d'Aujourd'hui, two architectural journals, was a failure in all senses, without any connection with neighbourhood associations, public administration, financial means and local opinion.

Finally, an alternative and a new way of foreseeing affordable housing, before the issue ofhome migrants becomes serious, was La Malagueira in Evora, Portugal (from 1977). The project by Alvaro Siza Vieira, very close to the tradition of Portugal's popular housing, created a neighbourhood with 
urban quality, avoiding modern typologies of blocks and towers, designing two types of houses with a patio for single families, and using a participatory process [15].

Step by step, in recent decades, the concepts of slums have changed, understanding that, instead of trying to eradicate slums, it is better for people and the environment to improve and consolidate them, providing them with the necessary urban infrastructure. The right to remain in their self-constructed neighbourhood, conserving its situation and social structure, is a priority. As mentioned above, removing and relocating are only required when people are living in hazardous situations, with contamination, risk of flooding or landslides. There are occasions that evictions could also be justified if public works are needed. However, development-generated evictions must follow rules based on human rights (of housing, neighbourhood and city) and basic principles about evictions, proposing resettlement and not compensation, as written in the United Nations principles and guidelines mentioned earlier. COHRE (Centre on Housing Rights and Evictions), an NGO, supervises the protection of these rights.

\section{Evolution in Housing Policies}

There have been different housing policies during recent decades. As explained, in the case of Latin America, after an initial rejection of slums, there was a short period of "self-construction policies", especially in the 1970s.

Currently, however, in South America, in the situation of dictatorships and the beginning of the neoliberal era, slums were urban and human fabrics to be demolished. Argentina's military dictatorship declared war on "villas miseria", with the "Plan de Erradicación de Villas de Emergencia" criminalising slums.

The end of this period, from the mid-1970s to 1990, coincides with the retreat of the World Bank (followed by States) in making housing policies. "Between 1972 and 1990 the Bank helped to finance a total of 116 sites-and-services and/or slums upgrading schemes in 55 nations" [5]. In this sense, there were some housing policies in the 1970s and they almost disappeared from 1990 onwards [16-18].

Furthermore, at the end of 20th century, social housing policies were brought back in some Latin American countries, such as Colombia, Brazil and Argentina. Thus, despite policy environments being in constant flux, people continued to fight for power through neighbourhood associations, international NGOs for the right to housing, and professionals working towards social justice. These individuals and collectives continued participating by proposing and experimenting with new policy solutions, such as promoting participation and open plan houses, which can grow and to be transformed over time [19].

\section{Resettlement}

There are intermediate operations between the total substitution of slums or favelas with a complete remodelling (such as the example of Parque do Gato in São Paulo, which was not successful) and the case of the programme Favela-Bairro to renew and empower favelas in Rio de Janeiro, building new housing behind slums.

In São Paulo, the SEHAB (Secretaria Municipal de Habitação) resettles part of the inhabitants of slums who live in areas where new infrastructure has to be constructed or in hazardous zones. New neighbourhoods, made up of blocks of flats and tower blocks, are planned to resettle the affected people, such as Nova Juaguaré (2006-2011) or Comandante Taylor (2008-2012).

After analysing the social housing for resettlement built in São Paulo, between 2005 and 2012, it was possible to identify three key elements of the housing layout that needed to be analysed in the planning new dwellings: the form, situation and uses of the kitchen; the relationship between rooms and toilets; and the presence or absence of outdoor space. In addition, other values, such as the intensity of natural light, appropriate ventilation and flexibility, could be checked when visiting and experiencing the spaces. Referring to new housing, having outdoor spaces with at least two hours of sunlight per day and nice views is determinant to achieving good quality of life, especially after the experience of 
lockdown during the COVID-19 pandemic. In Brazil, the distribution of outdoor spaces is diverse: low-rise dwellings may have a "veranda" at the entrance and a backyard or "quintal". The upper floors may have a simple balcony or a terrace. The lack of outdoor space could be compensated with access to the exterior through a corridor. In any case there should be green areas and accessible rooftops. Housing without terraces or access to outdoor space through a corridor is not acceptable.

In addition, the adequate urban relation in the interface between the new complex of blocks of flats and towers blocks and the old neighbourhood of refurbished favela is crucial. Public spaces for people to meet up and facilities to share are necessary to maintain social networks and not to convert this interface into a social frontier between new and old [20].

\section{Remaking Slums}

Remaking slums means acting on them from the inside and from their own logic, not through imposing external urbanism.

In Medellin, Colombia, some emblematic self-constructed neighbourhoods have been rebuilt, like the one in Moravia, which was constructed around a landfill and has a powerful urban and social area based on all types of recycling. Nowadays, Moravia possesses a strong urban structure, which is organic and commercial, similar to a medieval city pattern. Part of the neighbourhood was located in an area contaminated by debris. Necessary infrastructure of drainage, sewers and paths have been built, as well as new public amenities, such as the Cultural Centre, designed by the architect Rogelio Salmona. Therefore, the inhabitants living in contaminated and hazardous areas have been resettled to apartment buildings, in complexes such as Juan Bobo and Pajaritos.

In sum, remaking slums means restructuring them, introducing infrastructure, public facilities and public spaces. It also means envisioning them through planning, as has been done in the low-cost housing project Aranya, by the architect Balkrishna Doshi in Indore, India, since 1983, through his Vastu Shilpa Foundation for Studies and Research in Environmental Design [21].

The cases analysed include those where slums, favelas or shantytowns already exist, and the goal is to remodel them so as to improve them.

\section{The Favela-Bairro Programme}

The Favela-Bairro urban programme of slum upgrading and remodelling was created in Río de Janeiro in the 1990s, with the architect Luiz Paulo Conde as Mayor, Sergio Magalhães as Deputy on Housing and coordinator of the programme, and with the collaboration of Verena Andreatta, architect and manager for the programmes of urban rehabilitation. They proposed reinforcing the favela structure itself, introducing sanitation and connecting the favela better with the city. Favela-Bairro has promoted the development of new methods of intervention in the informal urbanism through participation. Started in 1994, this urban programme was funded by the Banco Interamericano de Desarrollo [22].

The characteristics of self-constructed neighbourhoods can improve if we understand them not as an incomplete way of modern urbanism, but as a specific form. This fits with Paola Berenstein Jacques' ideas, expressed in her book about the aesthetics of favelas in Rio de Janeiro and Salvador de Bahia from the point of view of shapes, structures and processes on three scales [23]. On a small scale, the huts, as a minimum and evolving shelter, consist of a collage of fragments and heterogeneous recycled materials; on a medium scale, the agglomeration of huts in slums are configured as chaotic and baroque labyrinths; and, at the same time, on a very large scale, the urban shape of a favela grows like ivy or shrubs in the interstices, vacant lots, hillsides and valleys. This pattern reminds us of the "rhizomes", as a shape generated by the process of spontaneous and continuous growth, explained by the poststructuralist theories of Gilles Deleuze and Félix Guattari [24]. 


\section{The Jorge Mario Jáuregui Method}

Highly representative of the Favela-Bairro programme are the interventions by Jorge Mario Jáuregui, first in favelas, such as Río das Pedras, Salgueiro, Morro dos Macacos. Later, with President Lula, the programme had a second call, within the PAC (Programa de Aceleração do Crescimento), that had new goals in the fields of energy, housing, urban planning and infrastructure, and that was dedicated to improving larger slums, such as Alemão, Manginhos and Rocinha.

With his method, Jáuregui synthesises many contributions, using a holistic approach: from land rights, with the establishment of the public sphere and the land tenure; from engineering, regarding infrastructure and sanitation; from sociology, in relation to the social study of the neighbourhood; from political science, taking into account an integrated local development; from geology, referring to geotechnical risks; from biology and ecology, studying the interaction of humans with their environment, the areas of preservation with ecological interest, and the contaminated and hazardous zones to transform; from urban planning, reconfiguring and reshaping centralities and creating open spaces; from architecture, with the contribution of the social environment through integrated buildings—-facilities and houses for resettlement—-following the urban structure of little pieces; from philosophy, relating to the poststructuralist concepts of "fold" and "rhizome"; and from psychology, following the methods of psychoanalysis and the understanding that true participation requires the intervention of every person.

Each project starts with the study of the rambling condition of internal natural flows, the growth trends of buildings and the social structure of each part of a slum. Jáuregui elaborates the interpretation of the structure of a zone based on overlaying the different maps of the neighbourhood, which have been drawn collecting data from observations and listening to the inhabitants. There is a harmony with mapping diagrammatic mechanisms in this method. In fact, Jáuregui, supporter of the post-structuralism of Deleuze and Guattari, places the concept of the diagram as a key tool in the centre of this work on the informal city [25]. He interprets diagrams as a footprint and scripture, as an active device. A diagram for Jáuregui is an attempt of an explicative abstraction, which concentrates and articulates information through drawing and heads towards what may exist. His diagrams become geometric diagnosis, always with an aesthetic trend to beauty, being abstract drawings similar to Japanese ideograms or the drawings and paintings by Vasily Kandinsky and Paul Klee.

One of the most crucial scheme-synthesis defines the limits and shapes of the different sub-neighbourhoods where inhabitants are grouped. These groups or areas are configured by their typological relationships and can be visible from Neighbourhood Committees, who receive the post and who interweave property transactions. In addition, the schemes include connections, centralities, articulations, accessibilities, limits, hazardous areas and areas of scenic and ecological value, existing public facilities and those that are missing.

The interventions are defined on two scales: one of objects-residential buildings for resettlement, nurseries, laundries, sport fields, squares and street furniture-and one of strategies, looking for interstices and where perspective lines are drawn, new streets are opened up, infrastructure is plotted, water is channelled, stairs are built and links are marked. Jáuregui empowered a participatory, open and complex system, thanks to the collaboration of architects and social scientists [26,27]. Each project reinforces the focus of intensity; enhances the neighbourhood with public facilities that have the same shape as the usual fragmented volumes of slums; promotes internal mobility; improves the relationship with the rest of the city by working on slum boundaries; and favours meeting places for residents. Each new intervention has a size and coloured shape similar to the fabric of the favela, which is treated as a rhizome where points and lines are introduced in order to improve and sanitise their implicit structure.

The acceptance and participation of the dwellers is essential to assume all the introduced transformations as their own. Jáuregui's team presents plans, models and renderings to dwellers to let them decide whether the project is acceptable or needs to be reframed. Consecutive homeopathic interventions are integrated in time, and transform the informal into a structured shape, from the 
social and the urban point of view, without intending that the city immediately becomes formal and conventional [28].

In conclusion, Jáuregui's diagrammatic method presents three tools of special importance: the "site identification maps" that overlay diverse information to delimit the sub-neighbourhoods that each Neighbourhood Committee manages; the proposal of a plan of strategies for infrastructures and improvements; and "ideograms", similar to geometrical schemes or diagrams, which plan the basic guidelines of the future project [29].

\section{The Intervention in "Villas Miseria" in Buenos Aires}

A representative and problematic example in Buenos Aires, remarkable for its urban centrality, social power and built development, which is very high, is Villa 31 or Villa Mugica, that has undergone a remodelling since 1990s. This is delimited by different major metropolitan infrastructures: the new port in the East; the elevated motorway, Presidente Arturo Umberto Illia, and other fast roads; the railway line General San Martín and the terminus station of Retiro; and the Retiro bus terminal. There have been several remodelling, refurbishment and resettlement proposals for this complex during the last three decades. The most recent proposal, approved as a preliminary draft in 2012, provides new housing, avenues, parks and public facilities. It is based on controlling the effect that heavy traffic has, associated with the port, and the enhancement of the neighbourhood social memory.

However, new works, in a wider and holistic, urban, architectural and social strategy, have been carried out since 2013, with better policies to systematically improve the "villas miseria" in Buenos Aires, which number 53, and in which 200,000 inhabitants live. The key strategy is to create and promote urban voids to open courtyards and gardens, making public ways and implementing urban infrastructure, following Patrick Geddes' criteria. All of these have been promoted by the Instituto de Vivienda de la Ciudad de Buenos Aires (IVC), and started to show the first results in 2019. With time and experience, a specific method for intervention in the villas has been created, including Villa 20, Villa Fraga and Villa Rodrigo Bueno, combining architecture and urbanism design with systematic social aid and accompaniment. These are cases that have had very good results, constantly learning from practice and reality. These will definitely become a new reference in the municipalities' housing policy to improve the villas or favelas.

In addition, to have high quality participatory processes, the ability to project and carry out specific improvements in each villa is needed. The major challenge is to make a positive balance between the parts constructed with new buildings and the reshaped ones. For this reason, it is imperative to create points of suture, public spaces, facilities and meeting sites between these two parts.

\section{Conclusions}

It is very important to remember that Elinor Ostrom, the author of Governing the Commons (1990) [30], claimed that human beings are not only motivated by pure competitiveness, corruption or coercion, but also by collaboration, solidarity, reciprocity and redistribution. She recognised specifically the characteristics and values of the so-called informal economy, in a wide approach that would include anything from the local indigenous communities or the survival in the slums, to the diverse contemporaneous experiences so as to improve, in a positive and creative way, this informal economy. Either way, Elinor Ostrom proved that the identification of the informal with destruction and chaos was totally false [31].

To conclude, despite the major difficulty, the wide diversity, complexity and hybrid nature of slums, and the social, urban and sanitary problems involved, some progress has been made in recent years, at least in some cities. Reviewing the different study cases and good practices we could learn which will be the most suitable option, between foreseeing, remaking or resettling, depending on each social, political, economical, urban and architectural situation.

As is stated at the beginning of this article, there are many studies on formal urban design and very few on informal growths, which include such a large number of people in the world. This period in 
the recent history of housing of remaking slums needs to increase in studies and proposals. This article is only able to present only one part of the very wide and different experiences around the world.

This review of some Latin American cases concludes quite a good evaluation of so-called "self-construction policies", such as Solanda in Quito, Equator, and Santa Catarina in Monterrey, Mexico, and their social and urban evolution; it explains the complexity of the holistic methodologies prepared to improve the favelas in Rio de Janeiro and points out the challenges in interventions, such as in São Paulo or Buenos Aires, creating new neighbourhoods behind the old slums, that are also improved by "sponging" and creating porosity for new streets and infrastructure, civic and green urban spaces and new facilities. The article supports a good balance between the new and the old, the neighbours that came to live in modern architecture and the ones that remain in the improved informal structure.

The future of housing and living for millions of inhabitants on our planet requires remaking slums and foreseeing affordable housing. This is a particularly major emergency due to the effects of the ongoing COVID-19 pandemic, with a very high level of infections in shanty towns, favelas and villas. For this reason, it is now more imperative than ever to review and recuperate the policies of social housing and the improvement of slums.

Funding: This research received not external funding.

Conflicts of Interest: The author declares no conflict of interest.

\section{References}

1. Serageldin, I. The Architecture of Empowerment. People, Shelter and Liveable Cities; Academy Editions: London, UK, 1997.

2. Architecture for Humanity. Design Like You Give a Damn: Architectural Responses to Humanitarian Crises; Metropolis Books: New York, NY, USA, 2006.

3. Stohr, K.; Sinclair, C. Design Like You Give a Damn (2): Building Change from the Ground Up; Abrams: New York, NY, USA, 2012.

4. Brillembourg, A.; Klumpner, H.; Coulombel, P.; Cruz, T.; Gans, D.; Harris, V.; Norton, J.; Palleroni, S.; Breda, A.V.; D’Urzo, S. Beyond Shelter. Architecture and Human Dignity; Metropolis Books: New York, NY, USA, 2011.

5. Davis, M. Planet of Slums; Verso: London, UK; New York, NY, USA, 2006; pp. 21, 70.

6. Gandhi, M.K. All Men Are Brothers; Continuum: New York, NY, USA; London, UK, 2007.

7. Montaner, J.M. La Arquitectura de la Vivienda Colectiva: Políticas y Proyectos en la Ciudad Contemporánea; Reverté: Barcelona, Spain, 2015.

8. United Nations. Basic Principles and Guidelines on Development-Based Evictions and Displacement; Office of the United Nations High Commissioner for Human Rights (OHCHR): Geneva, Switzerland, 2007.

9. Geddes, P. Cities in Evolution. In An Introduction to the Town Planning Movement and to the Study of Civics; Williams \& Norgate: London, UK, 1915.

10. Ward, C. Anrchy in Action; George Allen \& Unwin: London, UK, 1973.

11. Turner, J. Housing by People; Marion Boyars Publishers: London, UK, 1976.

12. Tyrwhitt, J. Patrick Geddes in India; Lund Humphries: London, UK, 1947.

13. Garcia-Huidobro, F.; Torres Torriti, D.; Tugas, N. El Tiempo Construye. In Time Builds; Gustavo Gili: Barcelona, Spain, 2008.

14. Aravena, A.; Iacobelli, A. Elemental. Manual de Vivienda Incremental y Diseño Participativo/Incremental Housing and Participatory Design Manual; Hatje Cantz: Ostfildern, Germany, 2012.

15. Mota, N. An Archaeology of the Ordinary. Rethinking the Architecture of Dwelling from CIAM to Siza; Delft University of Technology: Delf, The Netherlands, 2014.

16. Stephen, K. Vivienda: Un Entorno Propicio para el Mercado Habitacional; Banco Mundial: Columbia, DC, USA, 1993.

17. Rolnik, R. Guerra dos Lugares. A Colonização da terra e da Moradia na era das Finanças; Boitempo: São Paulo, Brazil, 2015. 
18. Rolnik, R. Urban Warfare: Housing under the Empire of Finance; Verso: London, UK, 2019.

19. Martín Hernández, M.; Díaz García, V. Visiones del Hábitat en América Latina. Participación, Autogestión, Habitabilidad; Editorial Reverté: Barcelona, Spain, 2018.

20. Montaner, M.A. Ferramentas Para Habitar São Paulo; SEHAB (Secretaria Municipal de Habitação): Barcelona, Spain, 2012.

21. Steel, J. The Complete Architecture of Balikrishna Doshi, Rethinking Modernism for the Developing World; Thames and Hudson: London, UK, 1998.

22. Montaner, J.M.; Muxí, Z. Arquitectura y Política. Ensayos Para Mundos Alternativos; Gustavo Gili: Barcelona, Spain, 2011.

23. Berenstein Jacques, P. Estética da Ginga. A Arquitetura das Favelas Através da obra de Hélio Oiticica; Casa de Palabra Rioarte PPGAN/FAUFBA: Rio de Janeiro, Brazil, 2001.

24. Deleuze, G.; Guttari, F. Mil Plateaux (Capitalisme et Schizophrénie); Les Editions de Minuit: Paris, France, 1980.

25. Deleuze, G. Pintura. El Concepto de Diagrama; Cactus: Buenos Aires, Argentina, 2007.

26. Machado, R. The Favela-Bairro Project. Jorge Mario Jáuregui Architects; Harvard University GSD: Cambridge MA, USA, 2003.

27. Jauregui, J.M. Estrategias de Articulación Urbana: Proyecto y Gestión de Asentamientos Periféricos en América Latina. Un Enfoque Transdisciplinario; FADU: Buenos Aires, Argentina, 2003.

28. Montaner, J.M. Sistemas Arquitectónicos Contemporáneos; Gustavo Gili: Barcelona, Spain, 2009.

29. Magalhaes Sanches, M. Diagrama e Informalidade: Un Estudio dos Registros de Jorge Maria Jáuregui. Master's Thesis, Universidade Estadual de Londrina, Londrina, Brazil, 2020.

30. Ostrom, E. Governing the Commons: The Evolution of Institutions for Collective Action; Cambridge University Press: Cambridge, UK, 1990.

31. Guha-Khasnobis, B.; Kanbur, R.; Elinor, O. "Beyond Formality and Informality" in Linking the Formal and Informal Economy: Concepts and Policies, Oxford Scholarship Online, September 2006. Available online: http://www.oxfordscholarship.com/view/10.1093/0199204764.001.0001/acprof-9780199204762 (accessed on 8 July 2020).

Publisher's Note: MDPI stays neutral with regard to jurisdictional claims in published maps and institutional affiliations.

(C) 2020 by the author. Licensee MDPI, Basel, Switzerland. This article is an open access article distributed under the terms and conditions of the Creative Commons Attribution (CC BY) license (http://creativecommons.org/licenses/by/4.0/). 